\title{
Case analysis on indirect economic benefits of industrial building construction
}

\author{
Yuan Qi $^{1}$, and Ning Kang ${ }^{1, *}$ \\ ${ }^{1}$ School of civil engineering, North China University of Technology, Beijing, 100144, China
}

\begin{abstract}
In this paper, the economic benefits of prefabricated buildings which are not directly reflected in the economic returns of investors are called indirect economic benefits. Based on the literature mining of the indirect economic relationship of a large number of prefabricated buildings, this paper constructs an analysis framework of indirect environment and social and economic benefits. Through BIM modeling software, the three prefabricated building models are modified into traditional building models. The indirect economic benefits of the project are calculated by using the index system. The functional relationship between the indirect economic benefits of prefabricated buildings and the assembly rate is established by using the SSPS statistical data processing software, which more intuitively shows the law of the indirect economic benefits of prefabricated buildings with the assembly rate It shows the impact of prefabricated building on environment and society, which is of great significance for the harmony between prefabricated building and society and environment, and the healthy and sustainable development of construction industry.
\end{abstract}

\section{Construction and modification of indirect economic benefit model}

The theory is as shown in figure below.

\begin{tabular}{|c|c|}
\hline Name & Carbon dioxide emission reduction \\
\hline Calculation rules & $\mathrm{EcO} 2=P \times \mathrm{QCO}_{2} \times 10^{-3} \times \mathrm{JCO} \times 10^{-3}$ \\
\hline $\begin{array}{l}\text { Symbolic } \\
\text { meaning }\end{array}$ & $\begin{array}{l}\text { Ec02:CO2 emission reduction value ( } 10000 \text { yuan) P: building area }\left(\mathrm{m}^{2}\right) \\
\text { Qc02: prefabricated building reduces carbon emissions by } \mathrm{kg} / \mathrm{m} 2 \text { per square } \\
\text { meter compared with traditional buildings Jco2:reference unit price of current } \\
\text { carbon trading market yuan / ton }\end{array}$ \\
\hline Name & Human health indicators \\
\hline Calculation rules & $\mathrm{E}_{\text {human }}$ health $=P \times \mathrm{Q} \mathrm{CO} 2 \times \mathrm{H} \times 10^{-4}$ \\
\hline $\begin{array}{l}\text { Symbolic } \\
\text { meaning }\end{array}$ & $\begin{array}{l}\text { E}_{\text {human health: economic benefits brought about by reducing health damage }} \\
\text { (10000 yuan) P: building area } \mathrm{m}^{2} \text { Qcoz: prefabricated buildings reduce } \\
\text { carbon emissions by kg/m² per square meter compared with traditional } \\
\text { buildings, } \mathrm{H}: 1 \mathrm{~kg} \mathrm{CO} \mathrm{CO}_{2} \text { emissions, social willingness to pay - WTP (yuan } / \mathrm{kg} \text { ) }\end{array}$ \\
\hline
\end{tabular}

Fig. 1. Brief introduction of environmental benefit theory.

\footnotetext{
* Corresponding author: 1016411710@qq.com
} 


\begin{tabular}{|c|c|}
\hline Name & Increase of labor productivity(IOLP) \\
\hline Calculation rules & $E_{\text {IOLP }}=\sum_{\mathrm{i}=1}^{\mathrm{i}=\mathrm{n}}\left(\eta_{2 \mathrm{i}}-\eta_{1 \mathrm{i}}\right) \times \mathrm{Q}_{\mathrm{i}} \times 10^{-4}$ \\
\hline $\begin{array}{l}\text { Symbolic } \\
\text { meaning }\end{array}$ & 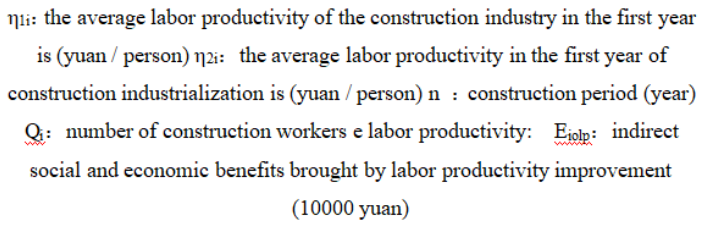 \\
\hline Name & Ease labor shortage(ELS) \\
\hline Calculation rules & $M_{\mathrm{i}}=F_{\mathrm{i}} \times \mathrm{S} \quad$ EELS $=\sum_{\mathrm{i}=1}^{\mathrm{n}}\left(X_{\mathrm{i}}-Y_{\mathrm{i}}\right) \times M_{\mathrm{i}} \times 10^{-4}$ \\
\hline $\begin{array}{l}\text { Symbolic } \\
\text { meaning }\end{array}$ & $\begin{array}{l}F_{\mathrm{i}} \text { : financial labor wage of the } \mathrm{I} \text {-year construction project (yuan) } \mathrm{S} \text { : Shadow } \\
\text { Wage conversion coefficient } \mathrm{M}_{\mathrm{i}} \text { : Shadow Wage of employees in the I-year } \\
\text { construction project (yuan) } \mathrm{X}_{\mathrm{i}} \text { : number of people required by traditional } \\
\text { construction mode } \mathrm{Y}_{\mathrm{i}} \text { : number of people required for prefabricated building } \\
\text { construction mode in the I-year } E_{E L S} \text { : indirect economic benefits brought } \\
\text { about by labor shortage (10000 yuan) }\end{array}$ \\
\hline Name & Construction safety improvement(CSI) \\
\hline Calculation rules & $E_{C S I}=\sum_{i=1}^{n}[(T \times Q i)-(N \times P i)] \times Y \times S \times M$ \\
\hline $\begin{array}{l}\text { Symbolic } \\
\text { meaning }\end{array}$ & $\begin{array}{l}\mathrm{T} \text { : Number of people required for traditional construction } \mathrm{N} \text { : number of } \\
\text { people required by prefabricated building construction mode } \mathrm{Y} \text { : number of } \\
\text { years that the accident person can continue to work } \mathrm{M} \text { : average annual wage } \\
\text { of Beijing construction industry ( } 10000 \text { yuan) } \mathrm{S} \text { : Shadow Wage conversion } \\
\text { coefficient } \mathrm{Q}_{\mathrm{i}} \text { : annual accident mortality rate of traditional construction } \\
\text { mode in China in the I year } \mathrm{P}_{\mathrm{i}} \text { : annual accident mortality rate of prefabricated } \\
\text { building mode in the I year } E_{C S I} \text { : indirect economic benefits brought by } \\
\text { improvement of construction safety performance ( } 10000 \text { yuan) }\end{array}$ \\
\hline
\end{tabular}

Fig. 2. Indirect social benefit theory.

\section{Case model analysis}

\subsection{Economic benefits of emission reduction}

Table 1. Calculation of economic benefits of emission reduction.

\begin{tabular}{cccccc}
\hline & $\begin{array}{c}\text { Steel } \\
\text { consumption } \\
\text { difference }(\mathrm{kg})\end{array}$ & $\begin{array}{c}\text { Wood } \\
\text { consumption } \\
\text { difference }\left(\mathrm{m}^{3}\right)\end{array}$ & $\begin{array}{c}\text { Concrete } \\
\text { consumption } \\
\text { difference }\left(\mathrm{m}^{3}\right)\end{array}$ & $\begin{array}{c}\text { Carbon } \\
\text { saving }\left(\mathrm{kgCO}_{2 / \mathrm{e}}\right. \\
\mathrm{q})\end{array}$ & $\begin{array}{c}\mathrm{CO} \text { emission } \\
\text { reduction value } \\
\text { (yuan) }\end{array}$ \\
\hline $1 \#$ & 13768.0 & 550.7 & 106.2 & 288320.8 & 8649.6 \\
$2 \#$ & 12662.2 & 508.2 & 97.1 & 249931.4 & 7498.0 \\
$3 \#$ & 13099.2 & 524.0 & 101.1 & 274348.3 & 8230.4 \\
\hline
\end{tabular}




\subsection{Human health indicators}

Table 2. Case calculation of economic benefits of physical health.

\begin{tabular}{cccc}
\hline & $\begin{array}{c}\text { Carbon } \\
\text { saving }\left(\mathrm{kgCO}_{2 / \mathrm{eq}}\right)\end{array}$ & WTP(yuan $/ \mathrm{kg})$ & $\begin{array}{l}\text { Economic benefits } \\
\text { Health }(10000 \text { yuan })\end{array}$ \\
\hline $1 \#$ & 288320.8 & $6.74 \times 10^{-6}$ & $1.943 \times 10^{-4}$ \\
$2 \#$ & 249931.4 & $6.74 \times 10^{-6}$ & $1.684 \times 10^{-4}$ \\
$3 \#$ & 274348.3 & $6.74 \times 10^{-6}$ & $1.849 \times 10^{-4}$ \\
\hline
\end{tabular}

\subsection{Increase of Labor Productivity (IOLP)}

Under the premise of considering the impact of project progress efficiency on labor turnover, the labor productivity of current housing industrialization can increase by $52 \%$

Table 3. Calculation of economic benefits of labor productivity.

\begin{tabular}{cccc}
\hline & $\begin{array}{c}\text { Construction personnel } \\
\text { (person) }\end{array}$ & Construction period (year) & $\begin{array}{c}\text { Economic benefits of labor } \\
\text { productivity (10000 yuan) }\end{array}$ \\
\hline $1 \#$ & 719 & 3 & 24028.9 \\
$2 \#$ & 702 & 3 & 23275.5 \\
$3 \#$ & 751 & 3 & 25596.5 \\
\hline
\end{tabular}

\subsection{Ease Labor Shortage (ELS)}

The construction period of the three projects in this paper is from 2018 to 2021, and the employment wages of the national construction industry are 63428 yuan, 69879 yuan and 74890 yuan respectively.

Table 4. Calculation of economic benefits of relieving the pressure of labor shortage.

\begin{tabular}{ccccc}
\hline & $\begin{array}{c}\text { Number of } \\
\text { construction workers } \\
\text { in traditional } \\
\text { construction mode } \\
\text { (person) }\end{array}$ & $\begin{array}{c}\text { Number of } \\
\text { construction workers } \\
\text { in prefabricated } \\
\text { construction mode } \\
\text { (person) }\end{array}$ & $\begin{array}{c}\text { Shadow Wage } \\
\text { conversion } \\
\text { coefficient }\end{array}$ & $\begin{array}{c}\text { Economic benefits } \\
\text { of relieving the } \\
\text { pressure of labor } \\
\text { shortage (10000 } \\
\text { yuan) }\end{array}$ \\
\hline $1 \#$ & 1700 & 719 & 0.65 & 13275.5 \\
$2 \#$ & 1700 & 702 & 0.65 & 13505.8 \\
$3 \#$ & 1800 & 751 & 0.65 & 14195.8 \\
\hline
\end{tabular}

\subsection{Improvement of construction safety performance}

The annual accident mortality rate of prefabricated building mode in China is $30 \%-50 \%$ lower than that of traditional building mode in China. the median value of $40 \%$ is taken in the calculation process. Assuming that the accident person can continue to work for 30 years, and the Shadow Wage conversion coefficient can be taken as 0.65. 
Table 5. Calculation of economic benefits of construction safety performance improvement.

\begin{tabular}{ccccc}
\hline & $\begin{array}{c}\text { Number of } \\
\text { construction workers } \\
\text { in traditional } \\
\text { construction mode } \\
\text { (person) }\end{array}$ & $\begin{array}{c}\text { Number of } \\
\text { construction workers } \\
\text { in prefabricated } \\
\text { construction mode } \\
\text { (person) }\end{array}$ & $\begin{array}{c}\text { Shadow Wage } \\
\text { conversion } \\
\text { coefficient }\end{array}$ & $\begin{array}{c}\text { Construction safety } \\
\text { performance and } \\
\text { economic benefits } \\
\text { (10000 yuan) }\end{array}$ \\
\hline $1 \#$ & 1700 & 719 & 0.65 & 140.5 \\
$2 \#$ & 1700 & 702 & 0.65 & 189.2 \\
$3 \#$ & 1800 & 751 & 0.65 & 202.1 \\
\hline
\end{tabular}

\section{Comprehensive analysis of case data}

Table 6. Indirect economic benefits of the project and its corresponding assembly rate.

\begin{tabular}{ccc}
\hline name & Assembly rate & Indirect economic benefits \\
\hline $1 \#$ & $50 \%$ & $3.74 \mathrm{bn}$ \\
$2 \#$ & $40 \%$ & $3.69 \mathrm{bn}$ \\
$3 \#$ & $60 \%$ & $3.99 \mathrm{bn}$ \\
\hline
\end{tabular}

\subsection{Curve regression equation}

The regression equation obtained from the regression analysis of Figure 1 is: $y=$ $0.001 \times 2-0.085 x+5.490$

\begin{tabular}{|c|c|c|c|c|c|}
\hline \multirow{2}{*}{ variable } & \multicolumn{2}{|c|}{ Coefficient of non standardization } & \multicolumn{3}{c|}{ Standardization coefficient } \\
\cline { 2 - 6 } & B & SE B & Beta & t & Sig \\
\hline $\begin{array}{c}\text { Assembly rate } \\
(\%)(z)\end{array}$ & -0.085 & 0 & -5.288 & - & - \\
\hline $\begin{array}{c}\text { Assembly rate } \\
(\%)(z 2)\end{array}$ & 0.001 & 0 & 6.232 & - & - \\
\hline constant & 5.49 & 0 & & - & - \\
\hline
\end{tabular}

Fig.3. Regression analysis.

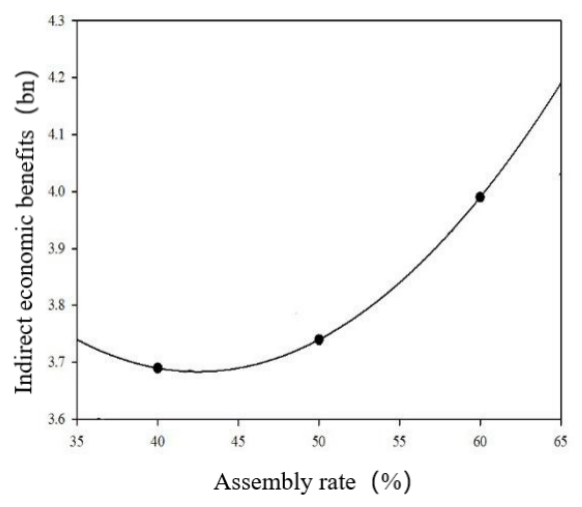

Fig. 4. Quadratic fitting curve. 


\section{Conclusion}

With the increase of assembly rate, the indirect economic benefit is increasing rapidly. And the research on the curve shows that the indirect economic benefit of prefabricated building is the lowest when the assembly rate is $42.5 \%$. This is because the traditional buildings provide a lot of employment opportunities, and make the construction period longer, so that the indirect social benefits are greater.

Supported by the Student Science and Technology Activity Project of North China University of Technology, Beijing Natural Science Foundation(8202018). This work was partially supported by"Beijing Natural Science Foundation(8202018) ”, the National Key Research and Development Program of China through the project, "Industrial Building Lifetime Performance and Level Assessment Technology and Standards" (2016YFC0701806)

\section{Reference}

1. Wang, Z., Hu, H., Gong, J., Framework for modeling operational uncertainty to optimize offsite production scheduling of precast components, Automation in Construction, 2018, 86 69-80.

2. Tam, V.W.Y., Fung, I.W.H., Sing, M.C.P., Ogunlana, S.O., Best practice of prefabrication implementation in the Hong Kong public and private sectors, Journal of Cleaner Production, 2015, 109 216-231.

3. Li, Z., Shen, G.Q., Xue, X., Critical review of the research on the management of prefabricated construction, Habitat International, 2014, 43 240-249.

4. Blismas, N., Pasquire, C., Gibb, A., Benefit evaluation for off-site $\mathrm{p}$ roduction in construction, Construction Management and Economics, 2006, 24 (2) 121-130.

5. Pons, O., 18 - Assessing the sustainability of prefabricated buildings, in: F. Pacheco-Torgal, L.F. Cabeza, J. Labrincha, A. de Magalhães (Eds.) Eco-efficient Construction and Building Materials, Woodhead Publishing, 2014, pp. 434-456.

6. Matic, D., Calzada, J.R., Todorovic, M.S., Erić, M., Babin, M., Chapter 16 Cost-Effective Energy Refurbishment of Prefabricated Buildings in Serbia, in: F. Pacheco-Torgal, C.-G. Granqvist, B.P. Jelle, G.P. Vanoli, N. Bianco, J. Kurnitski (Eds.) Cost-Effective Energy Efficient Building Retrofitting, Woodhead Publishing, 2017, pp. 455-487.

7. Salavatian, S., D’Orazio, M., Di Perna, C., Di Giuseppe, E., Assessment of Cardboard as an Environment-Friendly Wall Thermal Insulation for Low-Energy Prefabricated Buildings, in: A. Sayigh (Ed.) Sustainable Building for a Cleaner Environment: Selected Papers from the World Renewable Energy Network's Med Green Forum 2017, Springer International Publishing, Cham, 2019, pp. 463-470.

8. Kamali, M., Hewage, K., Life cycle performance of modular buildings: A critical review, Renewable and Sustainable Energy Reviews, 2016, 62 1171-1183.

9. Feng, K., Wang, Y., Lu, W., The Environmental Performance of Prefabricated Building and Construction: A Critical Review, in: ICCREM 2017: Prefabricated Buildings, Industrialized Construction, and Public-Private Partnerships, 2017.

10. Zhang, X., Skitmore, M., Industrialized housing in China: a coin with two sides, International Journal of Strategic Property Management, 2012, 16 (2) 143-157. 